PREPARED FOR THE U.S. DEPARTMENT OF ENERGY, UNDER CONTRACT DE-AC02-76CH03073

PPPL-3895

PPPL-3895

UC-70

Decommissioning of the Tokamak

Fusion Test Reactor

by

E. Perry, J. Chrzanowski, C. Gentile, R. Parsells,

K. Rule, R. Strykowsky, and M. Viola

October 2003

NM|

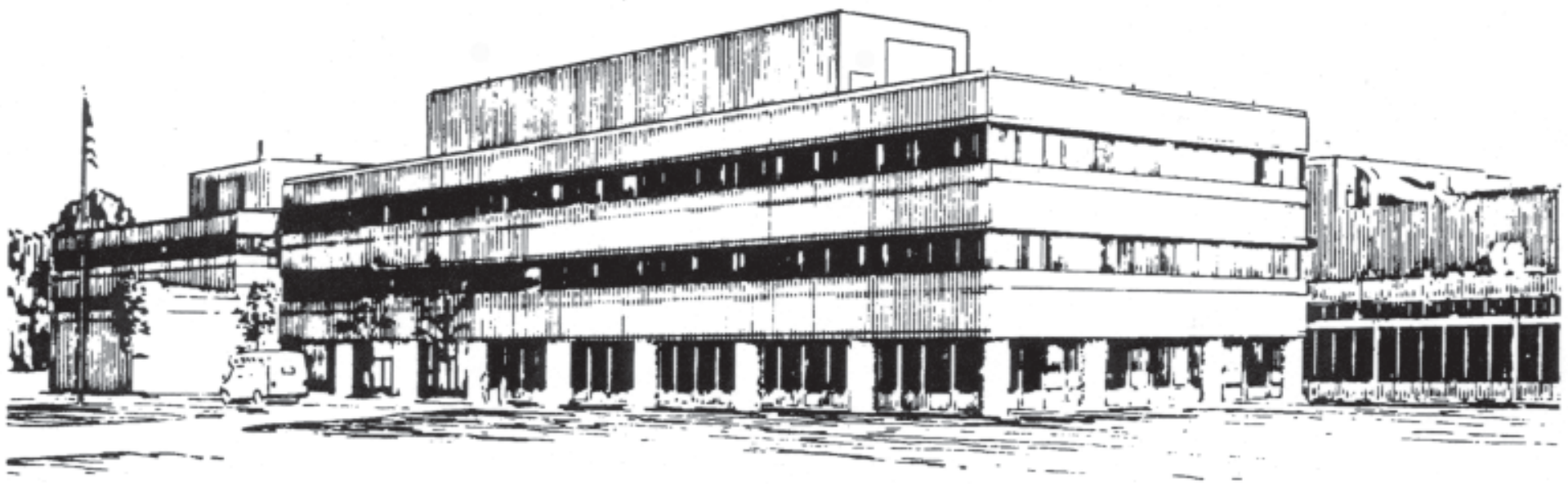

PRINCETON PLASMA PHYSICS LABORATORY PRINCETON UNIVERSITY, PRINCETON, NEW JERSEY 


\section{PPPL Reports Disclaimer}

This report was prepared as an account of work sponsored by an agency of the United States Government. Neither the United States Government nor any agency thereof, nor any of their employees, makes any warranty, express or implied, or assumes any legal liability or responsibility for the accuracy, completeness, or usefulness of any information, apparatus, product, or process disclosed, or represents that its use would not infringe privately owned rights. Reference herein to any specific commercial product, process, or service by trade name, trademark, manufacturer, or otherwise, does not necessarily constitute or imply its endorsement, recommendation, or favoring by the United States Government or any agency thereof. The views and opinions of authors expressed herein do not necessarily state or reflect those of the United States Government or any agency thereof.

\section{Availability}

This report is posted on the U.S. Department of Energy's Princeton Plasma Physics Laboratory Publications and Reports web site in Fiscal Year 2004. The home page for PPPL Reports and Publications is: http://www.pppl.gov/pub_report/

DOE and DOE Contractors can obtain copies of this report from:

U.S. Department of Energy

Office of Scientific and Technical Information

DOE Technical Information Services (DTIS)

P.O. Box 62

Oak Ridge, TN 37831

Telephone: (865) 576-8401

Fax: (865) 576-5728

Email: reports@adonis.osti.gov

This report is available to the general public from:

National Technical Information Service

U.S. Department of Commerce

5285 Port Royal Road

Springfield, VA 22161

Telephone: $1-800-553-6847$ or

(703) $605-6000$

Fax: (703) 321-8547

Internet: http://www.ntis.gov/ordering.htm 


\title{
Decommissioning of the Tokamak Fusion Test Reactor
}

\author{
E. Perry, J. Chrzanowski, C. Gentile, R. Parsells, K. Rule, R. Strykowsky, M. Viola \\ Princeton Plasma Physics Laboratory, P.O. Box 451, Princeton, New Jersey 08543
}

\begin{abstract}
The Tokamak Fusion Test Reactor (TFTR) at the Princeton Plasma Physics Laboratory was operated from 1982 until 1997. The last several years included operations with mixtures of deuterium and tritium. In September 2002, the three year Decontamination and Decommissioning (D\&D) Project for TFTR was successfully completed. The need to deal with tritium contamination as well as activated materials led to the adaptation of many techniques from the maintenance work during TFTR operations to the D\&D effort. In addition, techniques from the decommissioning of fission reactors were adapted to the $D \& D$ of TFTR and several new technologies, most notably the development of a diamond wire cutting process for complex metal structures, were developed. These techniques, along with a project management system that closely linked the field crews to the engineering staff which developed the techniques and procedures, via a Work Control Center, resulted in a project which was completed safely, on time and well below budget.
\end{abstract}

\section{INTRODUCTION}

The Tokamak Fusion Test Reactor began operations in 1982. From 1993 through 1997 TFTR was operated with tritium, a component of fusion fuel. During this four year period, TFTR successfully processed almost one million $\mathrm{Ci}$ of tritium of which about 53,000 $\mathrm{Ci}$ were delivered into the 80,000 liter vacuum vessel in support of fusion experiments. This operation with tritium left about 7,000 $\mathrm{Ci}$ of tritium in the vacuum vessel, mostly in the co-deposited layer on the graphite tiles and a relatively high concentration of surface contamination (10 M to $40 \mathrm{M} \mathrm{dpm} / \mathrm{cm} 2)$. In addition, the vacuum vessel was activated to levels around $50 \mathrm{mRem} / \mathrm{hr}$ on contact.

The mission of the TFTR Decontamination and Decommissioning (D\&D) Project was to: a) surgically remove items which could be re-used within the DOE complex, b) remove tritium contaminated and activated systems for disposal, c) clear the test cell of hardware so the area could be used for a future device, d) reclassify the D-site complex as a non-nuclear facility as defined in DOE Order 420.1 ( Facility Safety) and e) provide data on the D\&D of a large magnetic fusion facility.

\section{PLANNING FOR DECOMMISSIONING}

The planning for the D\&D of TFTR began in 1990 with a variety of studies involving persons from around the DOE complex who had experience with decommissioning reactors. A detailed preliminary D\&D plan was developed based on techniques being used to decommission fission reactors. A workshop for decommissioning experts was held at Princeton to discuss how to perform the hardest part of the decommissioning, the segmentation of the vacuum vessel. This workshop concluded that although the use of diamond wire cutting had a number of advantages, since it had never been used on metal vessels and there were issues with the stainless steel plating out on the diamond bits, the cooling of the diamond wire rope, and the pinching of the rope in the kerf, the preferred method for cutting the vessel would be with a plasma torch.

Planning continued at a low level in the following years with studies on disassembly sequences, cutting techniques, radwaste packaging and transportation. During the summer of 1999 a comprehensive Project Management Plan was developed and that October the Engineering group began preparing procedures for the field crews. The field crews did not start until there was a three month backlog of work for them to assure than they could be used efficiently.

\section{ISSUES}

At the beginning of the D\&D activities the TFTR activation and contamination levels were as follows: The Vacuum Vessel activity was approximately $25 \mathrm{mRem} / \mathrm{hr}$ (on contact), while the supporting structural steel and ancillary systems were at less than $2 \mathrm{mRem} / \mathrm{hr}$. The major concern was the inner surfaces of the vacuum vessel, vacuum pumping system and diagnostics, which were contaminated with tritium and tritiated compounds.

The vacuum vessel inner surfaces consisted of the stainless steel vessel inner wall, which was lined with carbon graphite tiles. These surfaces had been exposed during tritium operations and were coated with a co-deposited layer of tritium. Estimates and measurements indicated that as much as one-half gram $(5800 \mathrm{Ci})$ of tritium remained in the vacuum vessel.

The Torus Vacuum Pumping System, and to a lesser degree the individual diagnostic vacuum systems, were also considered to be at high risk for personnel exposure to tritium. The pump oil, which was assumed to have migrated throughout the entire vacuum pumping system, was especially hazardous since it contained organically bound tritium (OBT) which is readily absorbed through the skin. The biological half-life of compounds containing OBT is many times greater than that of tritium oxide, making the biological hazard to workers a real concern. Tritium exposure from fumes, filings and particulates generated during cutting, burning and grinding processes was considered to be the next highest risk for personnel and environmental exposure.

Experienced gained during line breaks into the nuclear boundary of TFTR during the D-T operations period proved extremely valuable in developing measurement and control techniques that ensured that the workers and the environment were protected from the radiological exposure hazards encountered during this project. 


\section{BASELINE PLAN}

The major facets of the D\&D project were: 1) safing and removal of all electrical and electronic hardware; 2) removal of items to be saved for re-use and the systematic removal of all non-contaminated components; 3) removal of the large structural components; 4) re-supporting the vacuum vessel for removal by segmentation; 5) stabilization of the in-vessel tritium by filling the vessel with lightweight ( $35 \mathrm{pcf}$ ) concrete; 6) segmentation of the vacuum vessel into ten sections using diamond wire cutting; 7) removal of the vacuum system piping; 8) disposal of materials.

\section{CUTTING TECHNOLOGIES}

Several novel technologies were deployed during TFTR D\&D which significantly reduced the cost and risk associated with the project.

Diamond wire cutting provided a method of cutting the TFTR vacuum vessel into 10 pieces which were able to be placed in Type A shipping containers for shipment and burial. Prior to TFTR D\&D, diamond wire cutting was typically used in stone quarries or in environments where concrete blocks needed to be cut. Full scale mockup testing at PPPL proved that diamond wire cutting could be used effectively to cut the stainless steel vacuum vessel when the vessel was filled with a light weight concrete. The employment of diamond wire cutting saved both resources and radiological exposure to personnel who were able, for the most part, to stay outside of the $25 \mathrm{mRem} / \mathrm{hr}$ general area radiation field that existed on and near most of the vacuum vessel components.

Crimping ends of tritiated pipes and lines proved to be an effective method of safely dismantling tritiated components for disposal. The use of industrial crimpers provided a method for isolating tritium contaminated surfaces in a manner which protected the workers and mitigated tritium off-gassing. In addition, pieces of pipes and tubing could be crimped and cut in a way that reduced dismantling labor costs while optimizing the size of the component that would fit into the waste disposal packages. The deployment of crimpers significantly reduced the quantity of removable tritium contamination at the work site, which led to a reduction in the quantity of radiological waste that needed to be disposed of.

Similar to the crimping tools were the rescue tools normally used by emergency response teams. These hydraulically powered tools featured a plunging blade, as well as other end effectors, and were used primarily to size reduce materials up to 4 inches across. The tools used were made by Holmatro and Champion.

Large industrial power saws, used in the decommissioning of fission reactors and chemical plants, provided an efficient means of cutting large metal components such as the TF coils, large diameter piping and the 92 ton umbrella structure. The inconnel and copper combination of the TF coils was cut using an extremely large Marvel bandsaw with carbide tipped blades. Large diameter piping (up to 36 inches) was cut using Wachs clamshell cutters which opened on a hinge to fit around the pipe, but then locked into place as a complete ring with the pneumatically driven cutter traveling around inside the ring. Structural components and PF coils were cut using pneumatic
Wachs guillotine saws which were powered hacksaws that strapped onto the piece to be cut. These saws could cut material up to 24 inches across and featured both automatic and manual feed control as well as remote control. In most saw cutting configurations the workers would set up the saw, lock the pieces in place, and the saw would perform the cut while the worker stood back and observed the cut from a location outside of the radiological area. This improved worker safety and kept their exposures lower in accordance with ALARA considerations.

\section{DIAMOND WIRE CUTTING}

By far, the most important technology developed for TFTR D\&D was the Diamond Wire Cutting (DWC) of the vacuum vessel. Ninety-inch diameter cylinders were constructed as full-scale mock-ups of the vacuum vessel and these cylinders were filled with concrete and then segmented with the DWC process. Every anticipated parameter of the actual task was mimicked during these trials. An enclosure surrounding the vacuum vessel and DWC equipment was added to provide containment for the concrete dust and metal particulates that would be generated during cutting. A negative pressure/ventilation control system was added to the enclosure. Slowly but surely, the techniques and tools that would be necessary to accomplish the fieldwork were developed in detail.

Industry experts that provided the initial setup operated the wire at approximately 3200 feet per minute (fpm), and 1200 lb. of tension. During testing at PPPL, the wire feed rate and tension were dramatically reduced to $450 \mathrm{fpm}$ and $150 \mathrm{lb}$, resulting in a much more efficient cutting rate and a much longer wire life. The slower speed had the additional benefit of lowering the inertia of the wire, reducing wire breakage and binding.

In industry, water is typically used to cool the wire. A two phase $\mathrm{CO}_{2}$ gas/liquid slurry replaced water as the wire-cooling medium, eliminating the accumulation of concrete slurry on the wire and greatly increasing its service life. The liquid component of the $\mathrm{CO}_{2}$ slurry was very effective at scrubbing the stainless steel residue from the diamond-impregnated beads, greatly prolonging their cutting life.

The vacuum vessel was filled with concrete to fix the internal tritium contamination in place and to assist in holding the kerf of the diamond wire cut open to reduce pinching on the wire. Aerated, lightweight $(35 \mathrm{lb} / \mathrm{cu}$. ft.) concrete was used instead of traditional $(150 \mathrm{lb} / \mathrm{cu}$. ft.) concrete in order to keep the weight down for lifting and transportation.

The segmenting of the vacuum vessel was by far the most difficult and critical aspect of the D\&D project. Although extensive prototyping and testing had yielded substantial improvement of the process, the actual segmenting of TFTR presented many challenges. The heart of this process was the wire rope with diamond-coated beads. A hydraulic motor drives the wire around a series of pulleys and ultimately around the circumference of the vacuum vessel. Readouts of the wire speed and tension were part of the operator s control panel. 


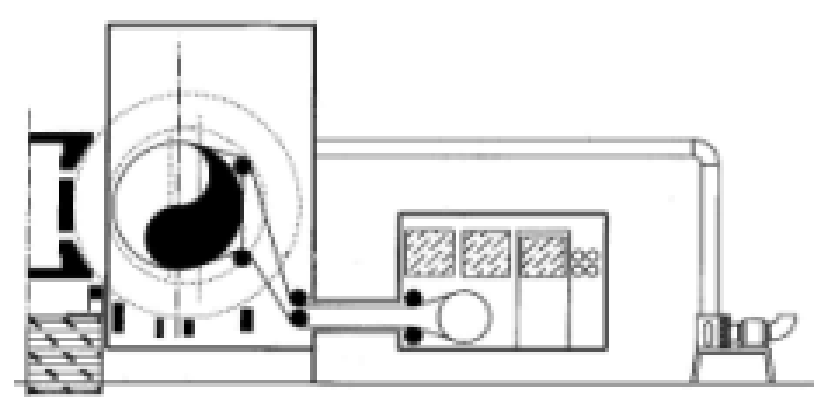

Fig. 1, DWC Saw and Pulley Arrangement

Several of the pulleys were mounted on gear racks and were remotely positioned during the cutting process. The proper adjustment of these pulleys was critical for prolonging the wire life. After the wire cut through the back of the vacuum vessel shell, the wire rope cut along the upper and lower edge of the vessel, not unlike a hack saw cutting through a round pipe. If the wire bends sharply around this edge, failure is eminent. The movable pulleys were positioned so that the rope s contact on the vessel edge produced a large bend radius, minimizing stress and increasing longevity. A camera was added to provide real-time visual feedback to the operators.

The hydraulic drive system was enclosed in the saw containment room, which was connected to the TF coil containment via a small access box. A large ventilation duct, connected to the top of the TF enclosure, would draw air (2000scfm) from openings in the saw containment room and through the entire containment system. Access into any part of the containment system was controlled, and required personal protective equipment including a supplied-air breathing apparatus. The access box, which incorporated swing out doors, allowed technicians to inspect and change the wire rope without having to enter the containment system.

Occasionally, the technicians had to enter the enclosures to perform work or maintenance. Double layers of protective clothing (cloth jumpsuits, rubber gloves and boots), as well as full-face, supplied-air breathing mask were required for entry. Initially, breathing air was supplied from a portable compressor system, however, after twenty minutes of operation the ballast tanks would heat up, resulting in hot air being sent to the workers. The air, which was supposed to provide a small measure of cooling to the encapsulated worker, was instead the cause of additional stress and fatigue. The locally located compressor pump also concentrated airborne odors and directed them to the workers, further aggravating the situation. The conversion to tank-car supplied air resolved all of these issues.

The technicians assigned to the diamond wire cutting team developed several tools that aided them in performing what became the most difficult task - freeing a jammed wire. Levers, pry bars and ultimately a small winch were all used in releasing stuck wires. Most jammed wires were released with a minimal amount of effort, requiring only a single entry into the TF enclosure. Occasionally, a wire became so severely jammed that several entries were required, and specialized hardware was developed.

It took approximately 25 hours of cutting time to completely cut through the vacuum vessel in one location.
This translates to the usage of two to three wire lengths, which typically last ten to twelve hours before failing

\section{PACKAGING AND DISPOSAL}

By the end of the TFTR D\&D project, approximately 53,000 cubic feet of radioactive and tritium contaminated waste had been disposed of. The deployment of novel procedures and technologies during D\&D led to an approximately $63 \%$ reduction in the amount of radioactive and contaminated waste materials from that which was initially estimated would be generated using conventional tooling and procedures. Since the waste disposal cost was a significant fraction of the total D\&D cost, this helped keep the overall project well below budget.

The planning efforts in this area concentrated on assisting the engineering group in identifying or developing cutting technologies which did not involve heat, water cooling, generation of fumes or small particulates since they would result in the generation of additional radioactive and tritium contaminated waste. Another area of planning involved identifying the type, weight and size of all waste generated by each removal task. This information was added to the project management database so that as tasks were rescheduled it was easy to generate a revised waste packaging/shipping profile for any given time period.

Early in the planning process, detailed container and transportation studies were performed to determine how to minimize the size reduction of components in order to minimize labor required, secondary waste generation and worker radiation exposure. For materials that were activated, but not contaminated, the preferred method of processing was to ship them in dump trailers or flatbed trailers to the Hanford Site for burial. Although the burial costs were higher at Hanford, the savings resulting from less size reduction and packaging more than off-set the burial costs.

For material that had tritium contamination it was usually internal contamination. This was handled by filling the item with a foam (or in the case of the vacuum vessel with lightweight concrete) to not only address the issue of the void space filler required for burial, but also to minimize the release of tritium when the component was cut for size reduction. Most of the items in this category were packaged in standard type A containers, however, the large vacuum pumping ducts and the ten sectors of the vacuum vessel were packaged in custom type A containers. The void space around these larger items was filled with smaller radioactive waste, rather than just void space filler, as another way of reducing the overall volume of waste shipped. Most of these packages went to the Nevada Test Site because of their lower cost for burial.

\section{PROJECT MANAGEMENT}

The success of the TFTR D\&D Project was due in part to the use of a Work Control Center (WCC) to provide a liaison between the engineering group that was developing the removal procedures and the field crews that performed the procedures. The Work Control Center provided centralized control of all work activities because all work required an Engineering Work Package (EWP), which included a procedure. The engineering group was responsible for defining work scope, conducting design reviews as required, preparing installation/removal procedures, and defining the prerequisites for the field work. The Work Control Center 
was responsible for reviewing the EWPs for completeness, ensuring that prerequisites were completed prior to issuing a package to the field, arranging for all permits, and releasing the packages to the field crews at the proper time. The field crews would perform the procedures exactly as they were written (procedure compliance was mandatory) and if any issues arose they immediately contacted the WCC who in turn arranged for the resolution of the issue. In the mean time the WCC issued another EWP to the field crew so they could continue to be effectively utilized. This process made it unnecessary to make engineering decisions on-the-fly in the field in order to keep things moving and hence resulted in better though out decisions while not compromising efficiency.

Another major contributor to the success of the project was the use of the principles of Integrated Safety Management (ISM). The five steps in ISM are: define the scope, analyze the hazards, establish hazard controls, work within the controls, and feedback / continuous improvement. As part of preparing the EWP, the engineering group prepared a Job Hazard Analysis (JHA) for each procedure. This JHA identified all of the potential hazards associated with performing the procedure and specified how these hazards would be mitigated. The JHA was reviewed and approved by a representative from Industrial Hygiene and was discussed with the field crew as part of the pre-job briefing that was required before starting each procedure. The ISM step of working within the controls was carried out by the field crews stopping work and returning the EWP to the WCC whenever there was an issue with performing the procedure. Finally, feedback and continuous improvement was incorporated into the process by requiring, for all procedures, a post-job briefing that was documented by the WCC and forwarded to the engineering group and the project manager for incorporation of lessons learned into future EWPs.

\section{SUMMARY}

The Decontamination and Decommissioning of the Tokamak Fusion Test Reactor took place between October 1999 and September 2002. Over 145 person-years of field work was performed during this period without serious injury or radiological exposure to any worker and with no unplanned radiological releases and no environmental impact. During this project over 2,000 tons of equipment was dismantled, 53,698 cubic feet of radioactive waste was disposed, 400 tons of concrete shielding was removed and stored, and 200 tons of lead was removed for re-use.

Because of the novel technologies and techniques employed during the project, a well trained staff, appropriate allocations of funds, and diligent scheduling and reporting which quickly identified work slippage and prompted reaction in a positive manner, the TFTR D\&D Project was completed safely, on schedule, and for $\$ 3.6 \mathrm{M}$ less than the original estimate of $\$ 40.3 \mathrm{M}$.

More information on the TFTR D\&D Project, including all presentations at a Lessons Learned Workshop, can be found at http://dd.pppl.gov

\section{ACKNOWLEDGMENT}

This work was supported by USDOE contract no. DEAC02-76-CHO3073.

\section{REFERENCES}

[1] Raftopoulos, S., Barnes, G., Chrzanowski, J., et al 2002, "Overview of the TFTR D\&D Program", $19^{\text {th }}$ IEEE/NPSS Symposium on Fusion Engineering, Atlantic City, New Jersey, USA.

[2] Gentile, C., Perry, E, Rule, K., et al 2003 ," The First Decommissioning of a Fusion Reactor Fueled by Deuterium-Tritium", $9^{\text {th }}$ International Conference on Radioactive Waste Management and Environmental Remediation. Oxford, England.

[3] Rule, K., Perry, E, Chrzanowski, J., et al 2003, " The Innovations, Technology and Waste Management Approaches To Safely Package and Transport The World's First Radioactive Fusion Research Reactor For Burial", $9^{\text {th }}$ International Conference on Radioactive Waste Management and Environmental Remediation. Oxford, England. 


\section{External Distribution}

Plasma Research Laboratory, Australian National University, Australia

Professor I.R. Jones, Flinders University, Australia

Professor João Canalle, Instituto de Fisica DEQ/IF - UERJ, Brazil

Mr. Gerson O. Ludwig, Instituto Nacional de Pesquisas, Brazil

Dr. P.H. Sakanaka, Instituto Fisica, Brazil

The Librarian, Culham Laboratory, England

Mrs. S.A. Hutchinson, JET Library, England

Professor M.N. Bussac, Ecole Polytechnique, France

Librarian, Max-Planck-Institut für Plasmaphysik, Germany

Jolan Moldvai, Reports Library, Hungarian Academy of Sciences, Central Research Institute for Physics, Hungary

Dr. P. Kaw, Institute for Plasma Research, India

Ms. P.J. Pathak, Librarian, Institute for Plasma Research, India

Ms. Clelia De Palo, Associazione EURATOM-ENEA, Italy

Dr. G. Grosso, Instituto di Fisica del Plasma, Italy

Librarian, Naka Fusion Research Establishment, JAERI, Japan

Library, Laboratory for Complex Energy Processes, Institute for Advanced Study, Kyoto University, Japan

Research Information Center, National Institute for Fusion Science, Japan

Dr. O. Mitarai, Kyushu Tokai University, Japan

Dr. Jiangang Li, Institute of Plasma Physics, Chinese Academy of Sciences, People's Republic of China

Professor Yuping Huo, School of Physical Science and Technology, People's Republic of China

Library, Academia Sinica, Institute of Plasma Physics, People's Republic of China

Librarian, Institute of Physics, Chinese Academy of Sciences, People's Republic of China

Dr. S. Mirnov, TRINITI, Troitsk, Russian Federation, Russia

Dr. V.S. Strelkov, Kurchatov Institute, Russian Federation, Russia

Professor Peter Lukac, Katedra Fyziky Plazmy MFF UK, Mlynska dolina F-2, Komenskeho Univerzita, SK-842 15 Bratislava, Slovakia

Dr. G.S. Lee, Korea Basic Science Institute, South Korea

Institute for Plasma Research, University of Maryland, USA

Librarian, Fusion Energy Division, Oak Ridge National Laboratory, USA

Librarian, Institute of Fusion Studies, University of Texas, USA

Librarian, Magnetic Fusion Program, Lawrence Livermore National Laboratory, USA

Library, General Atomics, USA

Plasma Physics Group, Fusion Energy Research Program, University of California at San Diego, USA

Plasma Physics Library, Columbia University, USA

Alkesh Punjabi, Center for Fusion Research and Training, Hampton University, USA

Dr. W.M. Stacey, Fusion Research Center, Georgia Institute of Technology, USA

Dr. John Willis, U.S. Department of Energy, Office of Fusion Energy Sciences, USA

Mr. Paul H. Wright, Indianapolis, Indiana, USA 
The Princeton Plasma Physics Laboratory is operated by Princeton University under contract with the U.S. Department of Energy.

\author{
Information Services \\ Princeton Plasma Physics Laboratory \\ P.O. Box 451 \\ Princeton, NJ 08543
}

Phone: 609-243-2750

Fax: 609-243-2751

e-mail: pppl_info@pppl.gov

Internet Address: http://www.pppl.gov 